\title{
ZKUŠENOSTI Z PROJEKTOVÉHO PŘÍSTUPU VE VÝUCE TECHNOLOGICKÝCH PŘEDMĚTŮ NA VŠCHT PRAHA - VÝUKA PRO PRAXI
}

\section{Hugo KitTel}

VŠCHT Praha, Technická 1905, 16628 Praha 6

hugo.kittel@vscht.cz

Došlo 24.9.21, přijato 15.10.21.

Klíčová slova: projektový přístup k výuce, metody řízení projektů, studentské projekty, moduly projektů, studijní opory

- https://doi.org/10.54779/ch120220067

\section{Úvod}

Jak vyplývá z podstaty chemie, která je zaměřena na změny složení a vlastností hmoty, jedná se o obor vyžadující hluboké teoretické znalosti. Také aplikace těchto poznatků do chemických technologií, která představuje základní poslání VŠCHT Praha jako technologicky zaměřené univerzity, vychází z náročných teoretických základů. S ohledem na významné uplatnění absolventů univerzity v praxi je zde také dlouhodobě vyučována teorie ekonomiky a managementu se zaměřením na chemický průmysl. I když studium zahrnuje relativně rozsáhlé laboratorní aktivity a praxi, klasifikace studentů je závislá především na dokonalém osvojení si a prezentování teoretických znalostí a $\mathrm{z}$ hlediska průběhu studia na individuálním výkonu a rozhodování studenta. Výsledkem je, že teoretické znalosti absolventi̊ VŠCHT Praha jsou obecně uznávané a oceňované, což dokazují výsledky různých srovnávacích studií i zájem zaměstnavatelů o absolventy univerzity.

Rozhodující část absolventů univerzity nastupuje do praxe $\mathrm{v}$ průmyslových podnicích, obchodních organizacích a nejrůznější institucích, jejichž vize, mise, cíle a plány nejsou založené na individuálních výkonech, ale na týmové práci, multiprofesním a projektovém př́stupu k řešení problémů, kde i excelentní teoretické znalosti nepředstavují dostatečný předpoklad úspěchu. Při diskusích o uplatnění absolventů univerzity zaměstnavatelé hovoří o formování nebo dotváření absolventů. S cílem reagovat na toto zjištění byl v roce 2016 na VŠCHT Praha formulován záměr na posílení projektového přístupu ve výuce technologických prredmětů. Projektovým př́stupem se přitom rozumělo uplatnění obecně známých postupů a metod řízení projektư ${ }^{1-3}$ při řešení studentských projektů na jednotném základě, s použitím shodných metod, formátů a opor, bez ohledu na konkrétní odborné zaměření studovaného předmětu a organizační zařazení ústavu. V tomto směru byla na MŠMT ČR podána žádost a byl $\mathrm{v}$ roce 2016 získán grant na projekt OP VVV nazvaný „Zkvalitnění vzdělávání - priorita VŠCHT Praha““4 a tato aktivita pokračovala od roku 2019 pod názvem „Chemické vzdělávání pro praxi (CHEMPRAX)“55.

Základním cílem grantu bylo zvýšit kompetenci studentů VŠCHT Praha pro zapojení do řešení reálných projektů, posílení dovednosti aplikovat teoretické znalosti a s tím související lepší uplatnění v praxi. Dílčí cíle představovaly:

- Porozumět aplikaci chemie v praxi současně v kontextu odborném, právním, ekonomickém, bezpečnosti a vlivu na životní prostředí.

- Vnímat rizika spojená s podnikáním v chemii a naučit se tato rizika eliminovat nebo minimalizovat.

- Seznámit se s reálnými postupy, metodami a standardy aplikovanými při implementaci technických projektů a s výsledky úspěšných technických projektů.

- Osvojit si zásady tvorby týmů, týmové práce, odpovědnosti za výsledky týmu a komunikace v týmu.

- Uvědomit si zásadní význam realizovatelnosti a ekonomické návratnosti technických projektů.

- Zlepšit dialog mezi studenty a pedagogy na základě použití definované a jednotné metodiky a pojmů při zpracování studentských projektů.

- Využít možnost klasifikovat studenty nikoliv pouze za individuální výkon, ale i za schopnost zapojit se do práce $\mathrm{v}$ týmu.

- Zaměřit pozornost studentů i na předměty mimo svoji odbornou specializaci, související s řízením a náklady projektů. Umožnit vytvářet týmy ze studentů více specializací, studujících na různých ústavech univerzity a tím současně prohloubit spolupráci mezi jednotlivými ústavy.

- Podpořit dialog mezi pedagogy technologických předmětů, jejichž součástí je studentský projekt.

$\mathrm{O}$ úsilí $\mathrm{i}$ výsledcích projektového př́stupu ve výuce na VŠCHT Praha byla pravidelně informována odborná veřejnost ${ }^{6,7}$.

\section{Výsledky a diskuse}

$\mathrm{Na}$ základě získaného grantu MŠMT ČR byl na VŠCHT Praha vytvořen tým z pedagogů, kteří mají zkušenost a využívají projektový př́stup při výuce technologických předmětů na univerzitě. Tým zahrnoval i pedagogy s předcházející dlouhodobou praxí v průmyslových chemických podnicích (např. se zkušeností předsedy představenstva a generálního ředitele významného chemického podniku), kteří nyní vyučují na VŠCHT Praha. Do týmu se dále podařilo zapojit i odborníky prrímo $\mathrm{z}$ inženýrské a výrobní praxe.

Byly rekapitulovány zkušenosti z projektového přístu- 
pu ve výuce na VŠCHT Praha napříč čtyřmi existujícími fakultami (dohromady 30 ústavů) a centrálními ústavy univerzity. Vypracovaná zpráva konstatovala, že projektový přístup $\mathrm{k}$ výuce je na univerzitě uplatňován $\mathrm{v}$ řadě technologických předmětů, což ostatně vyplývá i z technologického zaměření univerzity, ale $\mathrm{v}$ rozdílném rozsahu a obsahu podle zkušeností jednotlivých pedagogů, a že tyto zkušenosti a úspěchy nejsou dostatečně komunikované a sdílené napříč ústavy a fakultami univerzity.

K získání obecnějšího přehledu o implementaci projektového prŕstupu ve výuce a podnětů pro další činnost týmu byl proveden internetový průzkum publikovaných zkušeností s projektovým přístupem ve výuce na českých univerzitách. Nejednalo se o snadný úkol, protože termíny „projekt“ a „,ýuka“ jsou v internetovém prostoru mimořádně frekventované. Byly v tomto směru studovány aktivity 15 českých univerzit. Některé úspěšné zkušenosti z projektového prístupu ve výuce byly pak diskutovány i prímo $\mathrm{s}$ garanty těchto předmětů na jednotlivých univerzitách. Tento př́stup se velmi úspěšně využivá na některých fakultách Českého vysokého učení technického v Praze, České zemědělské univerzitě v Praze, Vysoké škole technické a ekonomické České Budějovice a Vysokém učení technickém v Brně, tj. univerzitách významně zaměřených na technologická řešení pro praxi. Získané poznatky představovaly inspiraci i pro implementaci projektového př́stupu ve výuce na VŠCHT Praha.

S cílem usnadnit využití projektového př́stupu ve výuce na VŠCHT Praha bylo na základě teorie řízení projektů vybráno a popsáno 12 základních modulů reálných technických projektů:

1. Sestavení týmu, spolupráce a komunikace $\mathrm{v}$ rámci týmu.

2. Definice cílů projektu.

3. Vypracování a kontrola harmonogramu projektu.

4. Analýza, vyhodnocení a zmírnění rizik.

5. Interakce projektu s legislativou, zejména s ohledem na bezpečnost, zdraví zaměstnanců a obyvatel, vlivu na životní prostředí a dlouhodobou udržitelnost.

6. Vypracování odborných studií souvisejících s projektem, jejich účel, formát a obsah.

7. Rozhodnutí o financování projektu, možné zdroje kapitálu a struktura rozpočtu.

8. Realizace projektu.

9. Převzetí projektu do zkušebního provozu a význam garančních testů v této souvislosti.

10. Uvedení projektu do trvalého provozu.

11. Poprojektové přezkoumání projektu.

12. Ukončení využívání a likvidace zařízení.

Doposud používaný přístup $\mathrm{k}$ řešení studentských projektů vycházel především z modulu 6 jako priority, tj. soustředil se na odborné řešení projektu. Dủležitost legislativy (např. použití nejlepších dostupných technologií), definování splnitelných parametrů pro garanční zkoušku, poprojektového přezkoumání nebo úvahy o budoucí likvidaci zařízení (každé zařízení má limitovanou životnost) představovaly nové podněty pro projekty.

Pro implementaci modulů ve studentských projektech byla vytvořena Metodická příručka ${ }^{8}$ obsahující stručný popis výše uvedených modulů a doporučení, jak je využít ve studentském projektu. $\mathrm{O}$ zařazení jednotlivých modulů do studentského projektu pak rozhoduje pedagog předmětu. Př́ručka dále obsahuje obecné i speciální studentské opory, zejména stručný česko-anglický slovník pojmů týkajících se řízení projektů, tabulku pro manažerský odhad návratnosti projektu, př́klad dokumentace skutečného projektu (pilotní jednotka pro Fischerovu-Tropschovu syntézu), průvodce farmaceutickým projektem, V-model prŕpravy, realizace a ověření projektu a návody pro vypracování projektu v konkrétních předmětech. Dále obsahuje stručné vzory dokumentů, např. zápis z porady týmu a formát zprávy o projektu. Dokumenty a studijní opory jsou $\mathrm{k}$ dispozici $\mathrm{v}$ české i anglické verzi.

Bylo vybráno celkem 8 technologických předmětů pro pilotní ověření projektu a pedagogové těchto předmětů byli zapojeni do činnosti týmu. Jednalo se o následující předměty:

1. „Procesní projekt“, Ústav chemického inženýrství, Fakulta chemického inženýrství. Č́ást projektů $\mathrm{v}$ tomto předmětu je vypracována $\mathrm{v}$ angličtině a připravuje se i výuka $\mathrm{v}$ angličtině pro zahraniční studenty.

2. „Inženýrství chemicko-farmaceutických výrob“, Ústav organické technologie, Fakulta chemické technologie.

3. „Jištění kvality technologických procesů“, Ústav organické technologie, Fakulta chemické technologie.

4. „Chemické speciality“, Ústav organické technologie, Fakulta chemické technologie. Předmět je vyučován též v angličtině pro zahraniční studenty pod názvem Fine Chemicals.

5. „Systémy řízení jakosti a zdravotní nezávadnosti“, Ústav konzervace potravin, Fakulta potravinářské a biochemické technologie.

6. „Informační systémy v ochraně životního prostředí“, Ústav chemie ochrany prostředí, Fakulta technologie ochrany prostředí.

7. „Elective Project“, Ústav technologie vody a prostředí, Fakulta technologie ochrany prostředí. Předmět je vyučován pouze $\mathrm{v}$ angličtině pro zahraniční studenty.

8. „Decentralizované zpracování odpadních vod“, Ústav technologie vody a prostředí, Fakulta technologie ochrany prostředí.

Pilotní předměty byly vybrány tak, aby do ověřování projektového př́stupu ve výuce byly zapojeny všechny fakulty VŠCHT Praha a byl podpořen dialog a předávání zkušeností mezi pedagogy těchto fakult. To např. zahrnovalo i účast pedagogů na obhajobách studentských projektů v jiných předmětech, než které vyučovali. Ověřování projektového prístupu $v$ pilotních předmětech bylo zahájeno v zimním semestru akademického roku 2018/2019 a výuka probíhá až do současnosti. Z výše uvedeného výčtu je patrné, že projektový př́stup ve výuce byl ověřován nejen napříc všemi fakultami univerzity, ale i na širokém spektru odborných témat. Snaha je nyní rozšírit výuku do dalších technologických předmětů na VŠCHT Praha.

Některá témata pro řešení studentských projektů 
v uvedených předmětech zadávají, konzultují a oponují významné externí inženýrské nebo průmyslové organizace. Pro studenty to představuje významný kontakt $\mathrm{s}$ chemickou praxí a s potenciálními budoucími zaměstnavateli.

Při pilotní výuce mohli studenti přípravu zpráv a prezentací projektů $\mathrm{v}$ angličtině konzultovat $\mathrm{s}$ pedagogem z Ústavu jazyků VŠCHT Praha.

Zejména $\mathrm{v}$ počátcích ověřování projektového přístupu ve výuce některé týmy studentů nechápaly, proč se nemohou soustředit pouze na odborné řešení projektů, na vypracování odborné studie (viz modul 6), proč je v této souvislosti nutné řešit i další témata a vypracovávat doplňující dokumenty a př́lohy, ale toto bylo postupně vysvětlováno především odkazem na realitu v praxi a diskusí s externími specialisty, kteří se studentských projektů zúčastnili.

Ověřování projektového př́stupu ve výuce ukázalo užitečnost nabídky určitých speciálních znalostí a dovedností. Z tohoto důvodu byl na Ústavu ekonomiky a managementu zaveden nový předmět „Aplikace projektového řízení“, který je zaměřen na využití software pro plánování projektů. Absolvování předmětu je spojeno s nabídkou pro studenty instalovat si a využívat speciální software po dobu práce na studentském projektu. $\mathrm{K}$ tomu univerzita zajistila dostatek softwarových licencí. Předmět bude vyučován i v angličtině. Další možnost přípravy na řešení studentských projektů představuje předmět „Základy projektového managementu“, jehož nabídka se z původně jen bakalářského stupně rozšíríla i na magisterský stupeň pro studenty všech fakult. V angličtině se předmět vyučuje pod názvem „Principles of Project Management“. Aby se zlepšilo vnímání projektového přístupu studenty jako důležité dovednosti pro řešení technologických projektů a porozumění odborným termínům řízení projektů, bylo dohodnuto, že základní pojmy a vybrané texty budou zahrnuty jako samostatná kapitola do aktualizace předmětu „Odborný anglický jazyk“, který je pro všechny studenty VŠCHT Praha povinný. K tomu bude využit i vytvořený českoanglický slovník pojmů týkajících se řízení projekti̊.

Od akademického roku 2021/2022 bylo dohodnuto, že do studentských projektů v předmětu „Procesní projekt““ na Ústavu chemického inženýrství se zapojí studenti z Ústavu ekonomiky a managementu. Tím se dosáhne spolupráce studentů různých specializací, napříč ústavy univerzity, podobně jako v chemické praxi.

Získaný grant MŠMT ČR byl primárně určen pro bakalářský a magisterský stupeň studia na VŠCHT Praha. Zkušenosti z implementace projektového přístupu ve výuce byly ale využity i pro nabídku tzv. měkkých dovedností (soft skills) v rámci nově akreditovaného doktorského studijního programu - workshopy „Řízení projektư“ a „Základy managementu“. Současně jsou pro toto studium nabízeny i předměty a software diskutované výše.

Pro podporu projektového přístupu $\mathrm{k}$ výuce proběhly na univerzitě speciální kurzy a přednášky. $V$ rámci aktivity CHEMPRAX to byl kurz pro pedagogy „Základy řízení technologických projektů v chemickém průmyslu“ a v rámci celoživotního vzdělávání prezentace „Projektová výuka“, která vycházela z poznatků zavádění projektového př́stupu ve výuce.

O průběhu projektu jsou pravidelně informováni studenti a pedagogové VŠCHT Praha na intranetu univerzity.

\section{Závěr}

Př́íprava a ověřování projektového přístupu ve výuce probíhalo na VŠCHT Praha 6 let $\mathrm{v} 8$ pilotních předmětech vybraných napříc jednotlivými fakultami univerzity. Jednalo se o předměty vyučované $\mathrm{v}$ českém i anglickém jazyce. Jako návod, jak postupovat při řešení projektů týmy studentů, byla vytvořena metodická příručka obsahující 12 základních modulů projektového prístupu a společné nebo speciální studijní opory pro implementaci tohoto prŕistupu. Probíhal dialog o projektovém přistupu ve výuce mezi pedagogy, který se dř́ve $\mathrm{v}$ takovém rozsahu na univerzitě neuskutečnil.

Očekává se, že projektový přístup ve výuce přispěje $\mathrm{k}$ lepšímu uplatnění absolventů na trhu práce, jejich rychlejší adaptaci na požadavky praxe, k zrychlení jejich kariérního růstu a že také posílí zpětnou vazbu těchto absolventů na pedagogické aktivity VŠCHT Praha. Předpokládá se také uplatnění projektového přistupu ve výuce v dalších předmětech na univerzitě.

Tato práce vznikla za podpory M $M \check{S} M T \check{C} R$ projektu Chemické vzděláváni pro praxi (CZ.02.2.69/0.0/ 0.0/18_056/0013354).

\section{LITERATURA}

1. A Guide to the Project Management Body of Knowledge, 6. vyd. Project Management Institute Newton Square, Pennsylvania 2017.

2. ČSN ISO 21500: Návod $k$ managementu projektu. Úřad pro technickou normalizaci, metrologii a státní zkušebnictví, Praha 2013.

3. Doležal J., Lacko B., Hájek M., Cingl O., Krátký J., Hrazdilová Bočková K.: Projektový management Komplexně, prakticky a podle světových standardů. Grada, a. s., Praha 2016.

4. Zkvalitněni vzdělávání-priorita VŠCHT Praha. MŠMT ČR, Praha 2016. CZ.02.2.69/0.0/0.0/16 015/0002374.

5. Chemické vzdélávání pro praxi, MŠMT ČR, Praha 2019. CZ.02.2.69/0.0/0.0/18_056/0013354.

6. Kittel H.: Teaching Project Approach in Technologically Oriented Subjects (in ECTN General Assembly). ECTN, Prague 2018.

7. Kittel H.: Czech Chem. Soc. Symp. 16, 456 (2018).

8. Kittel H. (ed.): Metodická príručka projektového př́stupu $k$ výuce $v$ technologických predmětech na VS̆CHT Praha. Nakladatelství VŠCHT (připravuje se k vydání), Praha. 
H. Kittel (University of Chemistry and Technology, Prague): Experience from the Project Approach in Teaching Technology Subjects at the University of Chemical Technology Prague - Teaching for Practice

A proposal was formulated at the University of Chemical Technology (UCT) Prague in 2016 to implement the project approach in teaching technology subjects. A grant was awarded for an Operational Program Research Development and Education project called "Education Improvement - UCT Prague Priority" from the Ministry of Education, Youth and Sports of the Czech Republic. The project's main goals were that UCT graduates would understand the application of chemistry in practice simultaneously in the context of the given field of study, as well as the law, economy, safety and environmental impact, realize the importance of viability and profitability of technical projects, learn about usable methods applied in the implementation of technical projects, and get acquainted with the principles of creation of teams and team work. A team of teachers and outside consultants from practice have been created. Using the Internet and personal contacts, experience with the use of project approach in teaching at the Czech universities has been gathered. Experi- ence from the project approach in teaching at UCT Prague has been summed up. Basic 12 modules of real-life technical projects have been defined and described in a Methodical Handbook which also includes a number of tools for students. A new subject has been created on the use of scheduling software. A total of 8 technology subjects have been selected for piloting of the project in 2018-2021, employing the created tools. The experience with teaching the pilot subjects was used in the lifelong education of the university teachers. The results will also be used for the teaching other technology subjects at UCT Prague. It can be expected that the project will contribute to a better employability of fresh graduates, their faster adaptation to the requirements of practice, a faster career growth, and that it will improve the feedback from graduates to the teaching staff and their activities at UCT Prague.

Keywords: project approach in teaching, project management methods, student projects, project modules, student supports

- Kittel H.: Chem. Listy 116, 67-70 (2022)

- https://doi.org/10.54779/chl20220067 